\title{
At-sea distribution and behaviour of a surface- feeding seabird, the lesser black-backed gull Larus fuscus, and its association with different prey
}

\author{
Philipp Schwemmer*, Stefan Garthe
}

Research and Technology Centre (Forschungs- und Technologiezentrum), University of Kiel, Hafentörn, 25761 Büsum, Germany

\begin{abstract}
The lesser black-backed gull Larus fuscus is a typical surface-feeding seabird with a widespread, patchy distribution in the SE North Sea. During the 1990s, breeding numbers along the German North Sea coast increased exponentially. Analyses of a multiple-year data set revealed changes in the at-sea distribution that seemed to reflect an increase in the numbers of breeding birds. Detailed recordings of feeding and resting behaviour at sea revealed area utilisation by the lesser black-backed gull. Observations at sea and dietary analysis revealed that swimming crabs Liocarcinus spp. are a major dietary item of this gull species. This natural food source was primarily captured close to the shore; at longer distances from the coast the gulls mainly fed on other natural prey items or discarded fishes from trawlers and avoided competition with other breeding gull species. During July and August 1990 to 1995 L. fuscus abundance was significantly correlated with fishing effort, while in May and June there was no such correlation. Time of day was the main environmental variable influencing the gulls' flight activity and indicated an association between activity and availability of their major natural prey, swimming crabs. Distinct patterns and changes in the at-sea distribution and foraging behaviour of L. fuscus in the SE North Sea reflect anthropogenic and natural influences in their habitats.
\end{abstract}

KEY WORDS: Gulls $\cdot$ Seabirds $\cdot$ Distribution $\cdot$ Behaviour $\cdot$ North Sea $\cdot$ Foraging $\cdot$ Prey $\cdot$ Habitat use

\section{INTRODUCTION}

In many parts of the world, seabirds choose different habitat types at sea and exhibit typical patterns of niche segregation in order to avoid competition (e.g. Hunt 1990, Ainley et al. 1992, Ribic \& Ainley 1997, Hunt et al. 1998). These relationships may be even more important for closely related species like gulls (Laridae) that live sympatrically. In this context, habitat selection is of primary importance and has been investigated intensively (e.g. Hunt \& Hunt 1973, Garthe et al. 1999). A recent study found that 4 breeding gull species in the German Bight, SE North Sea (the blackheaded gull Larus ridibundus, the mew gull L. canus, the herring gull $L$. argentatus and the lesser blackbacked gull $L$. fuscus) showed specific niche-segregation patterns, with that of the latter species being the most isolated (Kubetzki \& Garthe 2003). For the lesser black-backed gull, a particularly pronounced and widespread offshore distribution, even during the reproductive period, has been found in recent years (Camphuysen 1995, Kubetzki \& Garthe 2003); this species also shows major dietary differences from the other breeding gull species, indicating specialised foraging strategies. Both distribution and foraging behaviour are considered to be related to the strong population growth of this species in the SE North Sea (Garthe et al. 1999, Dierschke \& Hüppop 2003, Kubetzki \& Garthe 2003).

However, it is still unclear whether the distribution patterns of Larus fuscus at sea have changed during the last few years as a result of high variability in the foraging behaviour of lesser black-backed gulls or because of the exponential growth of the population that has been recorded since the mid-1980s (Garthe et al. 2000) and that might have forced the lesser black- 
backed gull to re-distribute in particular areas to avoid intraspecific competition. It is also not clear whether certain areas at sea are used more intensely than others, suggesting the use of particular natural or anthropogenic food sources.

Distribution patterns of this gull species have never been analysed using a multiple-year data set, nor have they been examined in relation to its feeding behaviour and diet. Such approach could reveal areas of special importance to this gull. In contrast to fishery bycatch and discards which are known to comprise an important supplement to its diet (e.g. Hunt \& Hunt 1973, Spaans et al. 1994, Walter \& Becker 1994, 1997, Camphuysen et al. 1995), the role of natural food (i.e. food unconnected with anthropogenic activities) is still unclear. There are several indications that this gull is able to live on pelagic prey species hunted in a natural way (Goethe 1975, Sjöberg 1989, Strann \& Vader 1992), but it is still not known what particular role this natural food plays in the gull's diet and in which way it may effect its at-sea distribution with regard to its high population numbers.

In this study, multiple-year data sets on lesser blackbacked gull distribution from 1990 to 2002 have been combined with newly developed recording schemes of behavioural patterns at sea using a standardised method (Camphuysen \& Garthe 2004). Gull abundance and behaviour at sea were related to the abundance of major prey types in diet samples collected in breeding colonies in the study area. Potential explanations for spatial and temporal patterns are presented that may help to understand the foraging strategies of this abundant surface-feeding seabird in the SE North Sea.

\section{MATERIALS AND METHODS}

The distribution and behaviour of Larus fuscus at sea were investigated in the German Bight, SE North Sea; the study area was 5 to $9^{\circ} \mathrm{E}$ and $55^{\circ} 30^{\prime}$ to $53^{\circ} 30^{\prime} \mathrm{N}$ (Fig. 1 ). Birds were counted from the top decks of various research vessels (deck heights from 2.2 to $14 \mathrm{~m}$ above the sea surface) in accordance to the method of Tasker et al. (1984) and Garthe et al. (2002). Briefly, each bird swimming within a $300 \mathrm{~m}$ wide transect (distance from the sides of the vessels, usually travelling at about 10 knots) was counted. Birds flying inside the transect were recorded by the 'snapshot' method; i.e. arbitrarily counting only those birds which flew into or across the transect at every full min to avoid counting any individual more than once (Tasker et al. 1984). As the probability of detecting birds swimming close to the vessel is

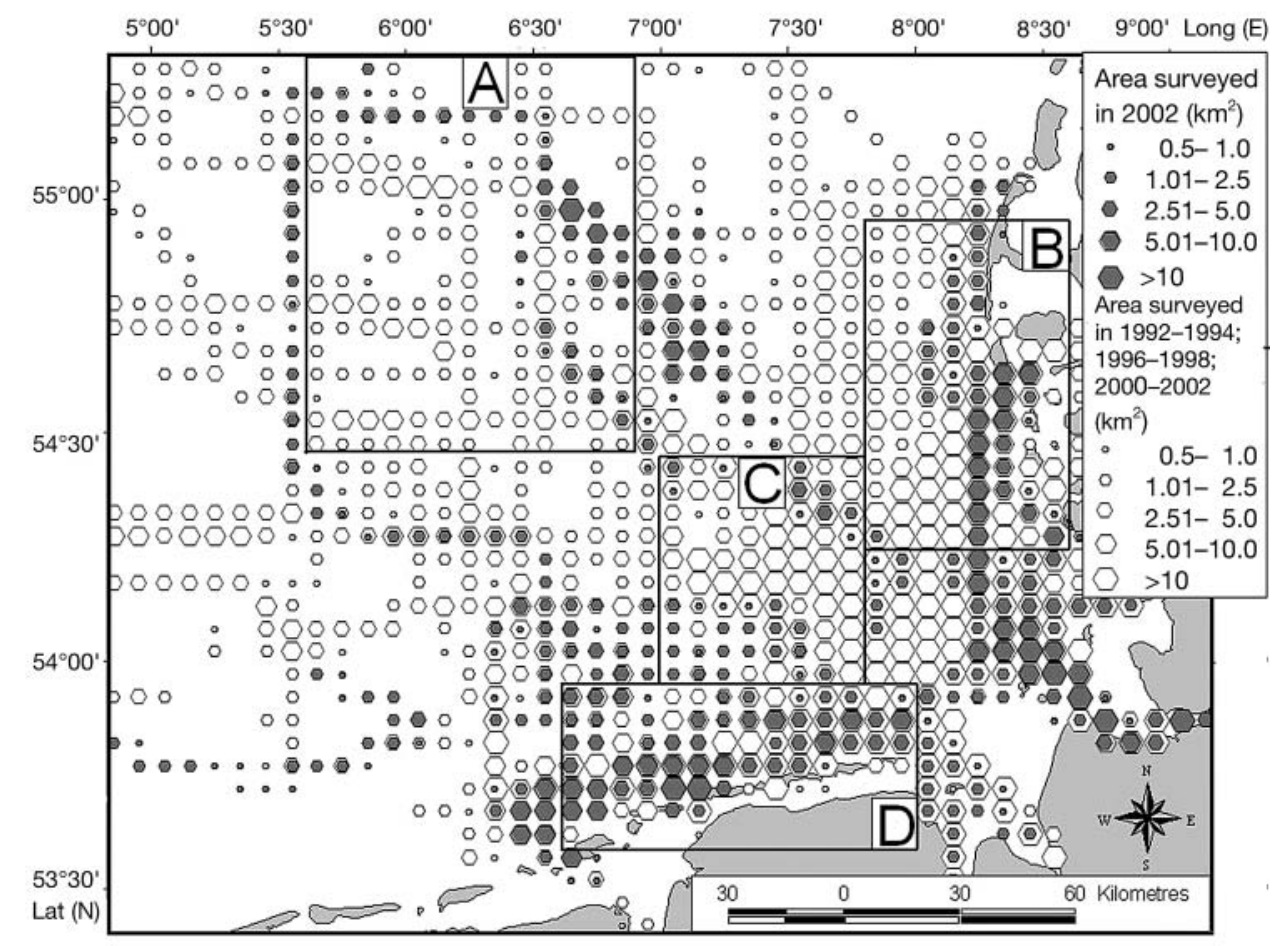

Fig. 1. Study area in the SE North Sea. Open symbols indicate areas surveyed (i.e. observer effort) in 1992-1994, 1996-1998 and 2000-2002; filled symbols indicate areas surveyed for behaviour analyses in 2002 only. Boxes A to D are for statistical comparison between areas. A: offshore; B: North Frisian; C: central; D: East Frisian 
higher than that of detecting more distant individuals, the density of swimming birds was corrected by multiplying by a correction factor of 1.3 (Garthe 1997 after Buckland et al. 1993). Densities were estimated by dividing the sum of all individuals recorded per 3' latitude $\times 6^{\prime}$ longitude grid (grid cell-size equivalent to ca. $36 \mathrm{~km}^{2}$ ) by the total area surveyed within that grid (i.e. observer effort; open symbols in Fig. 1). The data used for investigating distribution patterns were taken from the 'German Seabirds at Sea' database (Garthe \& Hüppop 2000) Version 3.04 (September 2002) for the months May to August of the years 1990 to 1992, 1994 to 1996 , and 2000 to 2002 . To detect variation in gull distribution between the 3 time intervals and between different areas of the German Bight, 4 specific areas (Boxes A to D in Fig. 1) with a similar observation effort were compared using $\chi^{2}$-tests for goodness of fit. In order to run the test, expected values for gull densities were calculated for each of the 4 areas.

Behaviour at sea was analysed from May to August 2002 (observer effort indicated by filled symbols in Fig. 1) following the descriptions of Ashmole (1971) and Camphuysen \& Garthe (2004). We chose 3 different classes of behaviour: (1) searching for natural food (gulls flying with their heads pointing down towards the sea surface or actively hunting or feeding); (2) association with fishing vessel (gulls in vicinity of an operating fishing vessel searching for discards or by-catch or resting after having fed from trawler wastes); (3) resting (gulls resting inactive on the sea surface, sleeping or preening). Different feeding techniques were also recorded as 4 categories: (1) dipping (taking up prey in flight while barely touching the sea surface); (2) pecking (sitting on the water while pecking up tiny prey items); (3) shallow plunging (diving for prey); (4) surface-seizing (sitting on surface while feeding on large prey which could not be swallowed at once). The 3 behavioural categories were analysed on a spatial and on a daily time scale applying $\chi^{2}$ statistics. For the daily scale, the day was divided into morning, mid-day and evening (03:00-08:59 h, 09:00-14:59 $\mathrm{h}$ and 15:00-19:59 h UTC respectively); morning and evening hours were combined in order to obtain comparably large sample sizes. Prey items were recorded as often and as accurately as possible before being ingested by the gulls.

Distance to the coast is a major factor affecting seabird distributions in the German Bight (Garthe 1997), and the 3 behavioural categories were therefore examined as a function of this factor by calculating the distance of each central point of the $3^{\prime}$ latitude $\times 6$ ' longitude grid cells from the closest point on land (including Wadden Sea islands but excluding island of Helgoland) and comparing with gull densities in the particular grid cell using $\chi^{2}$-tests.
The distribution of gulls can be closely related to trawler presence, although this does not seem to have had any significant effect on the distribution of the lesser black-backed gull at the temporal and spatial scales studied so far (e.g. Camphuysen 1995, Garthe 1997). To test for any possible relationship at a large spatial and temporal scale, international fishing-effort data (British, Danish, Dutch, German and Norwegian trawlers) from 1990 to 1995 (Jennings et al. 1999) were compared with Larus fuscus distribution recorded over the same period. Spearman rank-correlation was used to compare total fishing effort in 16 ICES-rectangles with the mean densities of lesser black-backed gulls in each rectangle for 2 different annual periods.

The activity of gulls in a breeding colony can be influenced by various temporal, physical or meteorological factors (e.g. Burger 1976, Garthe et al. 1999). In addition to behaviour recorded at sea, flight-activity patterns were recorded near a lesser black-backed gull colony on the island of Norderney (see Fig. 2) for $7 \mathrm{~d}$ in June and $5 \mathrm{~d}$ in July 2002. Gulls heading out to sea or returning to the colony and flying across a line of $800 \mathrm{~m}$ length set arbitrarily along the colony edge were counted during daylight hours. The flight activity of birds leaving and returning to the colony was calculated and compared to time of day UTC, tide, wind force, wind direction and abundance of fishing vessels, using a 5-way ANOVA.

To assess the importance of prey items taken by the gulls at sea, their diet was analysed on the basis of pellets collected during the egg stage and the chick-rearing period in the colony on Norderney in 2002 and in the colony on Amrum in 2003 (see Fig. 2). Following the method of Duffy \& Jackson (1986), the frequency of occurrence of each food category was determined. Duffy \& Jackson (1986) pointed out biases in the use of this method, in that hard components may be overestimated and soft items such as small fishes are likely to be underestimated. However, as the present study mainly focuses on trends in the diet of major prey categories and compares these to those in other dietary studies of the lesser black-backed gull, results using this method should be valid. More detailed analyses for the same or nearby colonies using similar methods have recently been published (Garthe et al. 1999, Kubetzki \& Garthe 2003).

\section{RESULTS}

\section{Distribution at sea}

The lesser black-backed gull showed a widespread distribution, and appeared in high numbers in both coastal waters and offshore areas up to more than 
$100 \mathrm{~km}$ distance from the coast in all years (Figs. 2 to 4). Densities differed significantly between 2 of the 4 areas over the 3 time periods ('North Frisian nearshore box': $\chi^{2}=233.86, p<0.001$; 'central box': $\chi^{2}=93.78, p<$ 0.001 ), whereas there was no significant difference for the 'offshore box' and the 'East Frisian nearshore box' $\left(\chi^{2}\right.$-test for goodness of fit).

The sites of highest densities changed from 1992 to 2002: until 1998, maximum numbers were recorded in the centre of the study area, while in 2000 to 2002 numbers near the North Frisian coast increased. This resulted in significantly different densities between the 4 boxes for all 3 time periods (1992 to 1994: $\chi^{2}=$ 381.93; 1996 to $1998: \chi^{2}=298.59 ; 2000$ to $2002: \chi^{2}=$ 500.78; p $<0.001)$.

\section{Behaviour at sea}

Spatial distribution. During the research cruises in $2002,55.3 \%$ of all lesser black-backed gulls recorded were classified into the 3 behaviour categories. Most individuals were associated with fishing vessels (25.4\%) and therefore distribution of these gulls was strongly ag- gregated (Fig. 5), with high numbers in coastal waters (mostly associated with shrimp trawlers) and highest numbers at 40 to $60 \mathrm{~km}$ distance from the shore (mostly associated with beam trawlers: see below). Birds actively searching for natural food $(14.0 \%)$ were much more evenly distributed and widespread over the whole study area (Fig. 6), but appeared in highest numbers close to the shore as well as at 60 to $100 \mathrm{~km}$ distance from the coast (see below). Resting gulls (15.9\%) were only recorded within $60 \mathrm{~km}$ of the coast (Figs. $7 \&$ 8), while $44.7 \%$ of the birds flying fell into no behaviour category. Densities within the 6 distance classes (Fig. 8) were significantly different among the 4 behavioural categories $\left(\chi^{2}=591.12 ; \mathrm{df}=15 ; \mathrm{p}<0.001\right)$.

Temporal variation in behavioural categories. The behaviour of lesser black-backed gulls at sea was partly influenced by time of day. The proportion of all individuals searching for natural food was highest during the morning and evening hours and decreased significantly during the mid-day hours, whereas the proportion of gulls associated with fishing vessels showed the opposite pattern (Table 1). For resting gulls, no significant difference was recorded as a function of time of day.

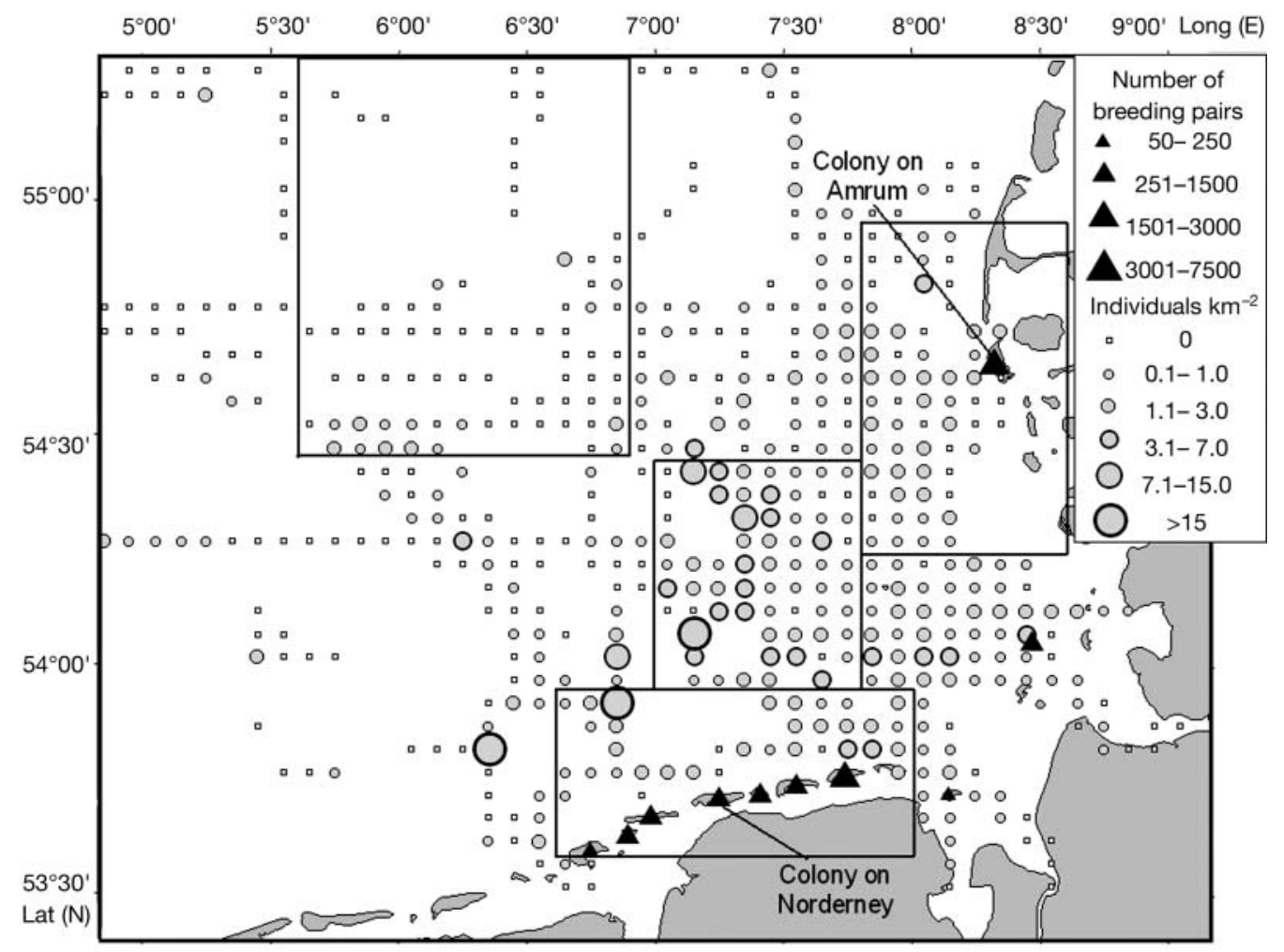

Fig. 2. Larus fuscus. Distribution of lesser black-backed gulls in May-August 1992-1994. Triangles represent breeding pair numbers (only colonies with > 50 pairs shown); data taken from Südbeck \& Hälterlein $(1994,1995)$ and Hälterlein \& Südbeck (1996) 


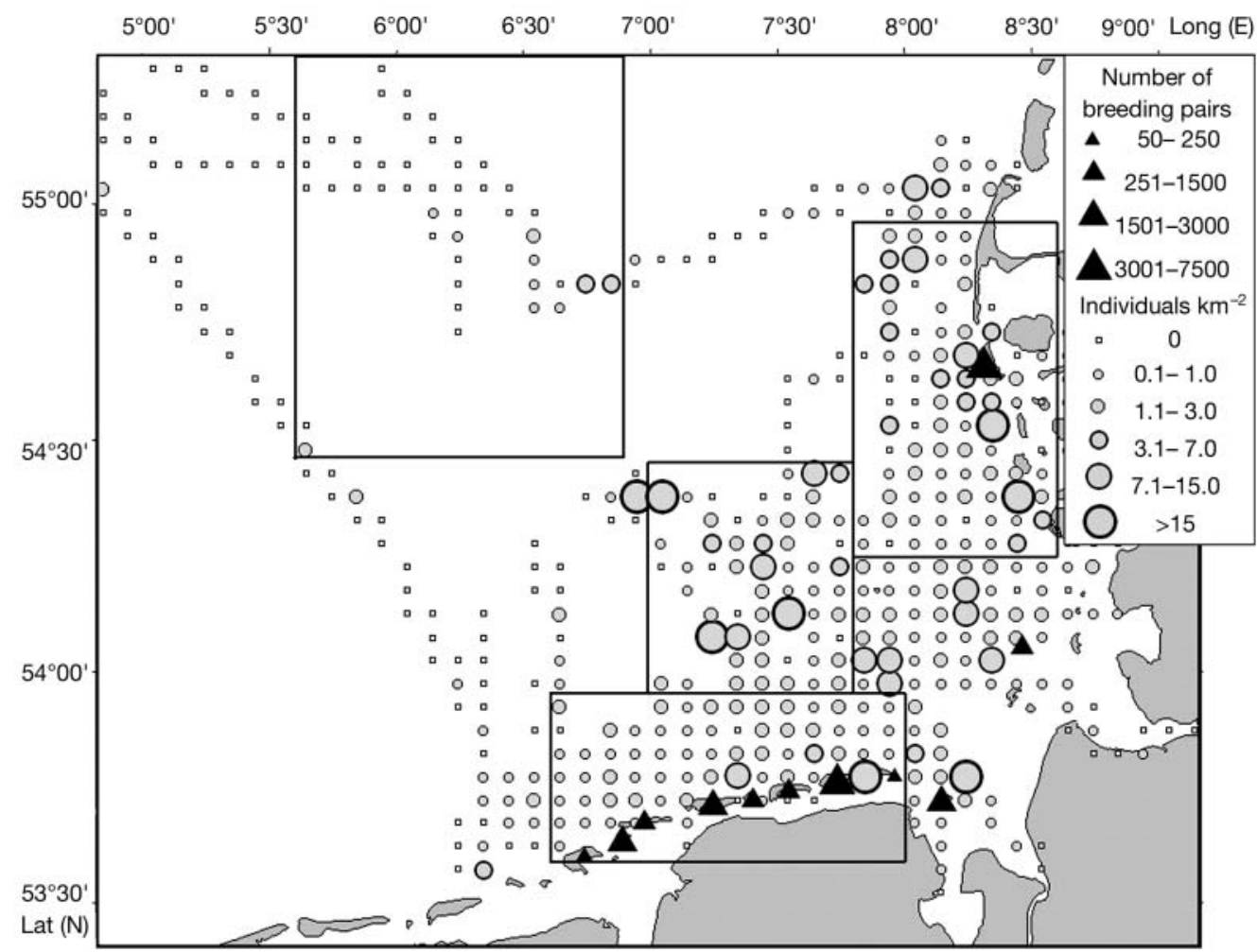

Fig. 3. Larus fuscus. Distribution of lesser black-backed gulls in May-August 1996-1998. Triangles represent breeding pair numbers (only colonies with >50 pairs shown); data from Hälterlein \& Südbeck (1998), Südbeck \& Hälterlein (1999, 2001)

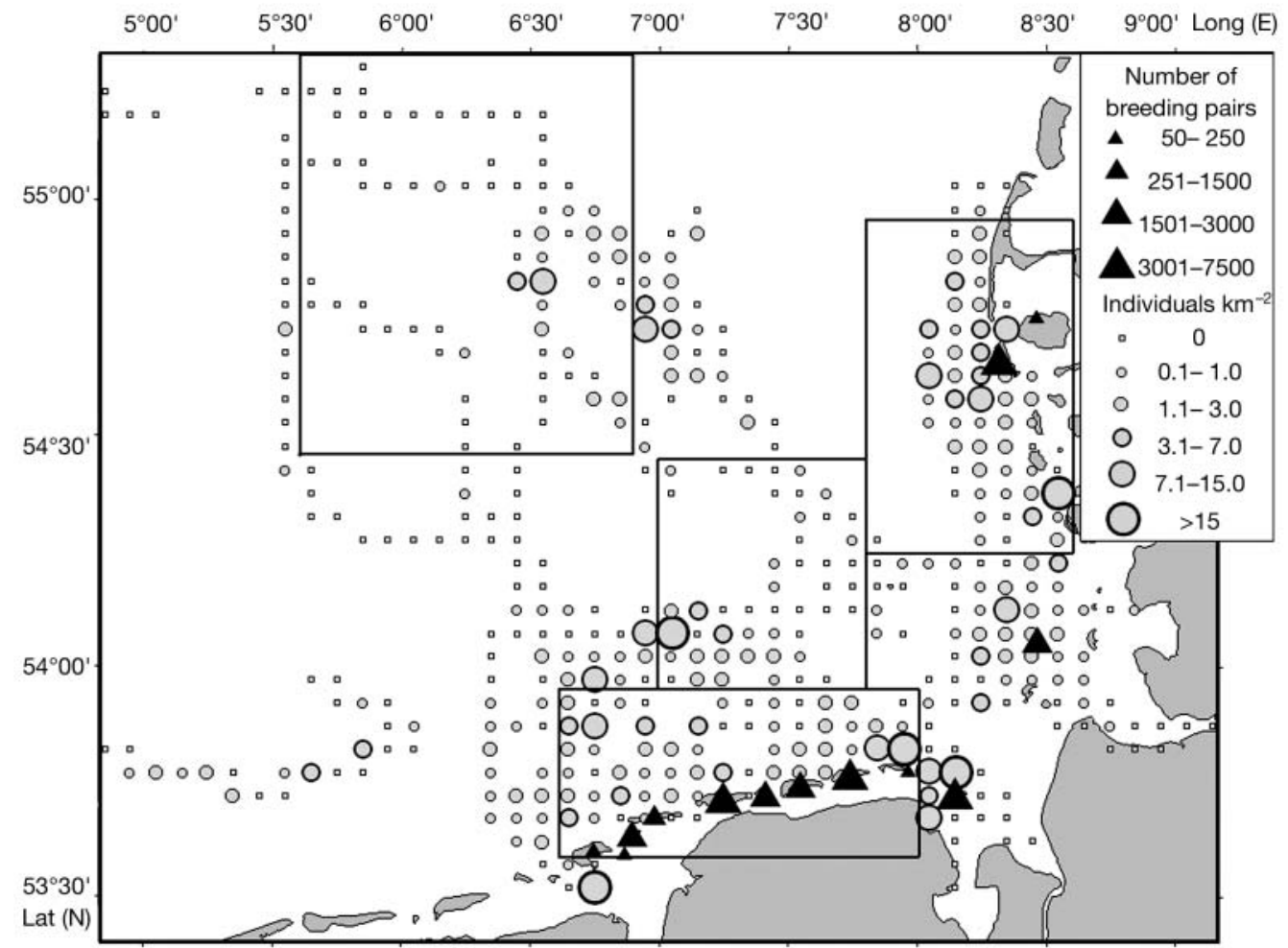

Fig. 4. Larus fuscus. Distribution of lesser black-backed gulls in May-August 2000-2002. Triangles represent breeding pair numbers (only colonies with > 50 pairs shown); data from Südbeck \& Hälterlein (2001) 


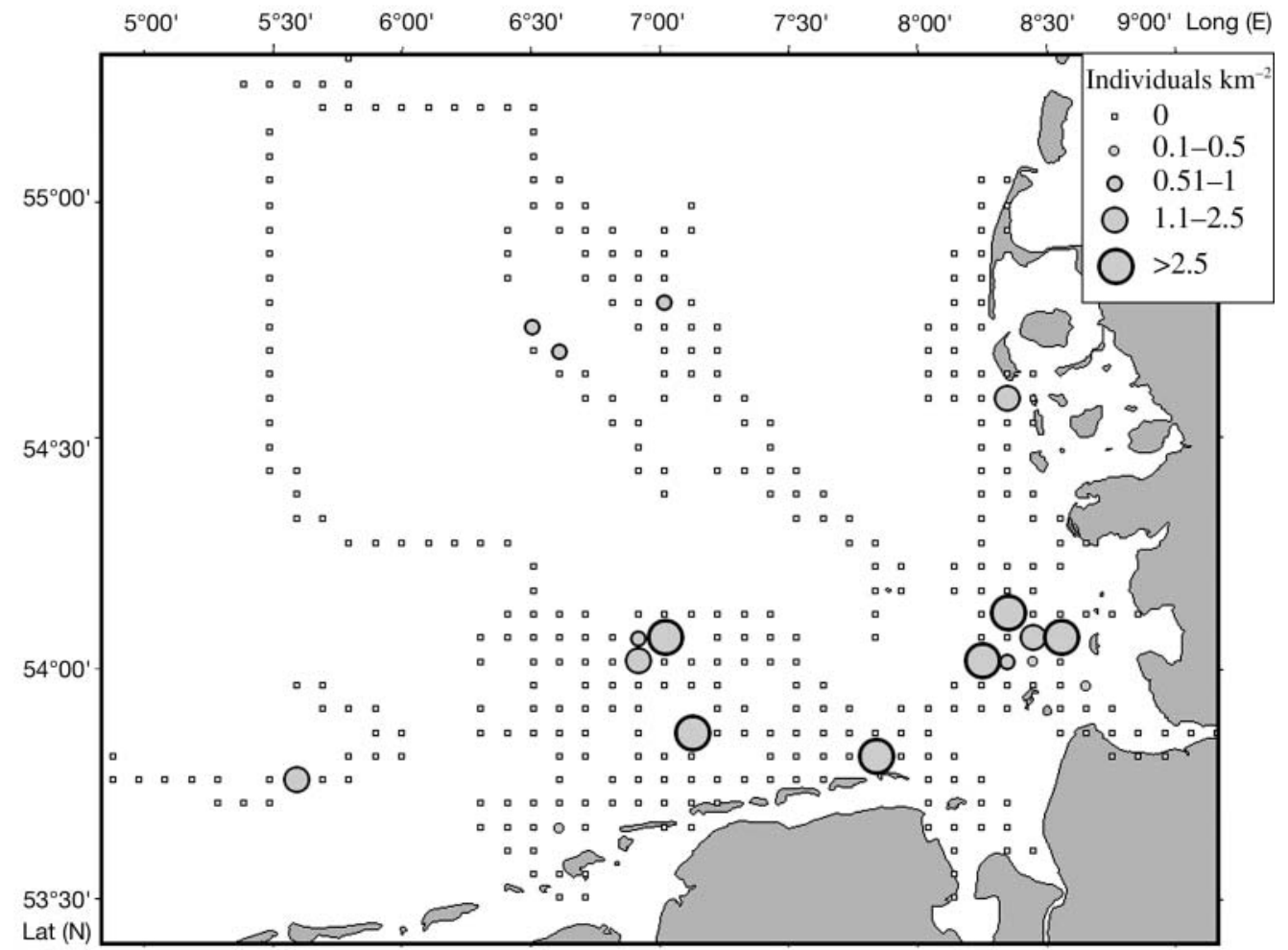

Fig. 5. Larus fuscus. Distribution of lesser black-backed gulls in May-August 2002 associated with fishing vessels

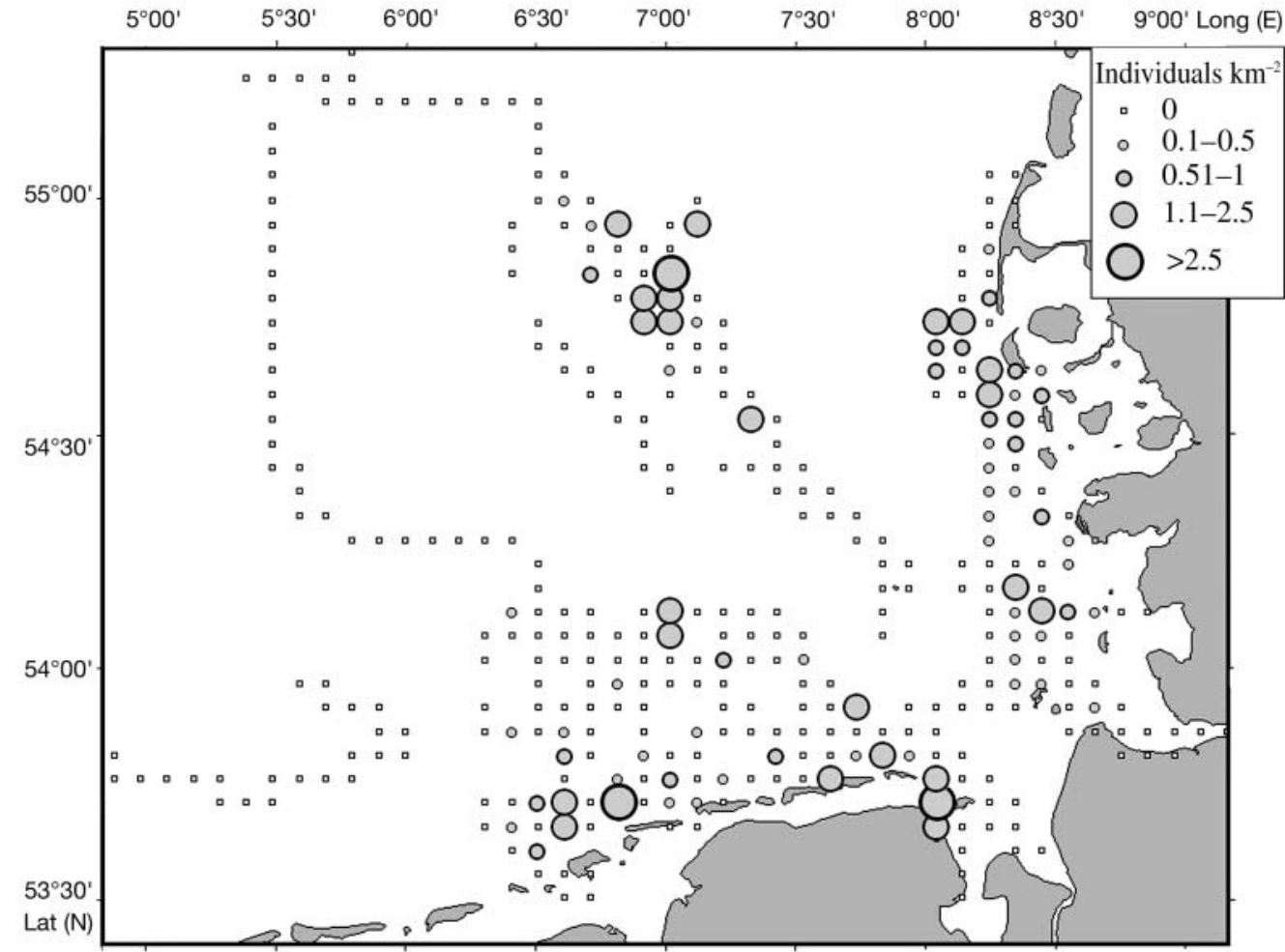

Fig. 6. Larus fuscus. Distribution of lesser black-backed gulls in May-August 2002 searching for or feeding on natural food 


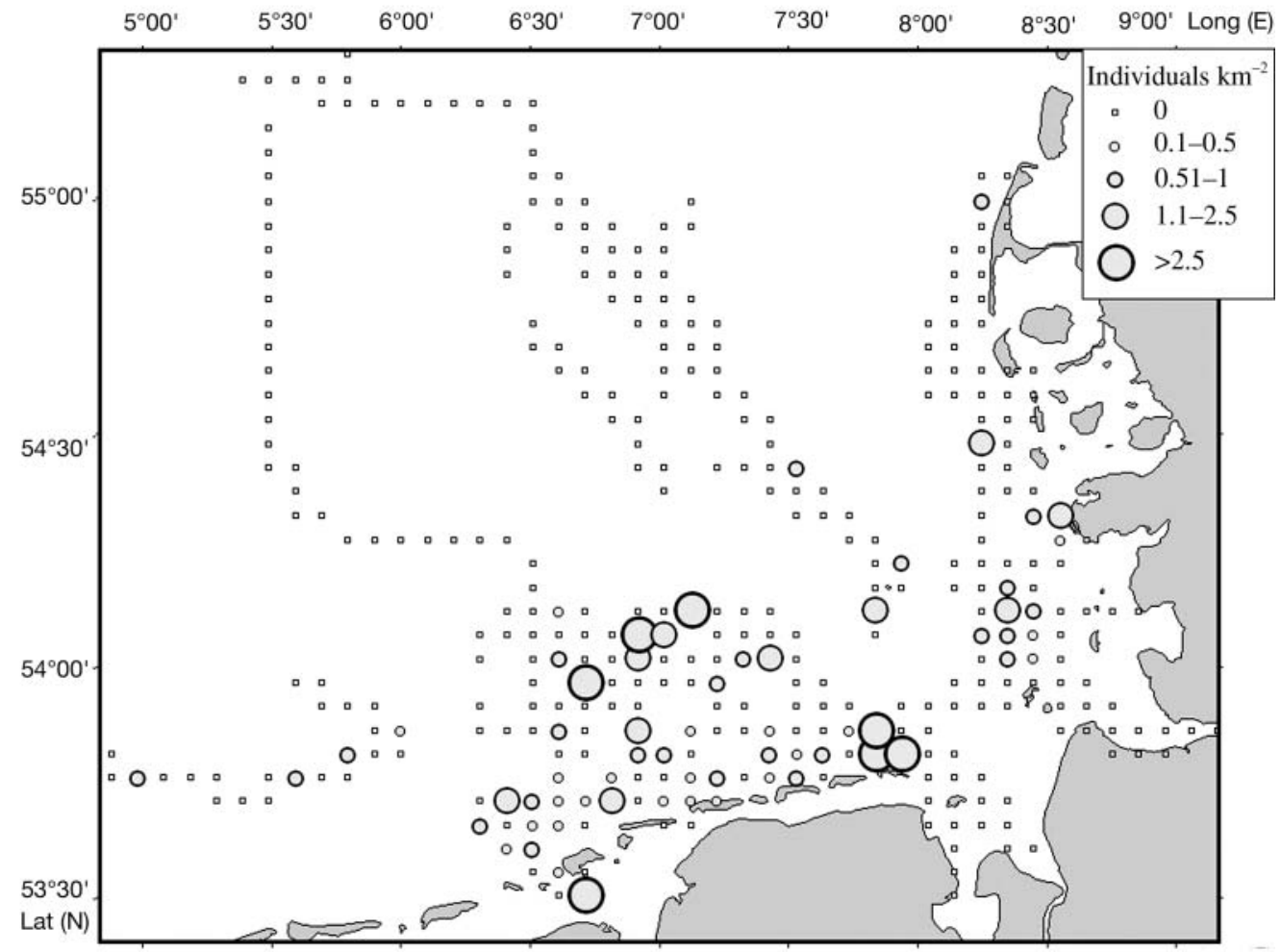

Fig. 7. Larus fuscus. Distribution of resting lesser black-backed gulls in May-August 2002

\section{Feeding behaviour}

Items carried or hunted were recorded for lesser black-backed gulls searching for natural food; a total of 85 crustaceans (25 of these were Liocarcinus spp.), 39 fishes, 3 birds, 1 starfish and 1 bivalve were identified. As crustaceans seemed to be the most common food of naturally feeding individuals, this food item was studied in more detail.

First, there was a distinct spatial pattern in feeding on crustaceans in the study area. Most crustacean prey were recorded only at distances of up to $30 \mathrm{~km}$ from the coast (Fig. 9), and differences between the 4 boxes were significant $\left(\chi^{2}=54,39\right.$; p < $0.001)$. Second, there was a temporal variation in the feeding on crustaceans, both as a function of time of year and time of day. In regard to season, there was an increase in feeding events from May to August 2002 (May: 11; June: 21; July: 27; August: 41) $\left(\chi^{2}\right.$ $=19.28 ; \mathrm{df}=3 ; \mathrm{p}<0.001)$ - observer effort was nearly constant each month. In regard to time of day, 46 crustaceans were taken during the morning $(0.12$ crustacean con- sumed gull ${ }^{-1}$ present) and 25 during the evening (0.1 gull $\left.^{-1}\right)$ while during the mid-day hours only 14 crustaceans were taken $\left(0.02\right.$ gull $\left.^{-1}\right)\left(\chi^{2}=66.58\right.$; df $=2$; $\mathrm{p}<0.001)$.

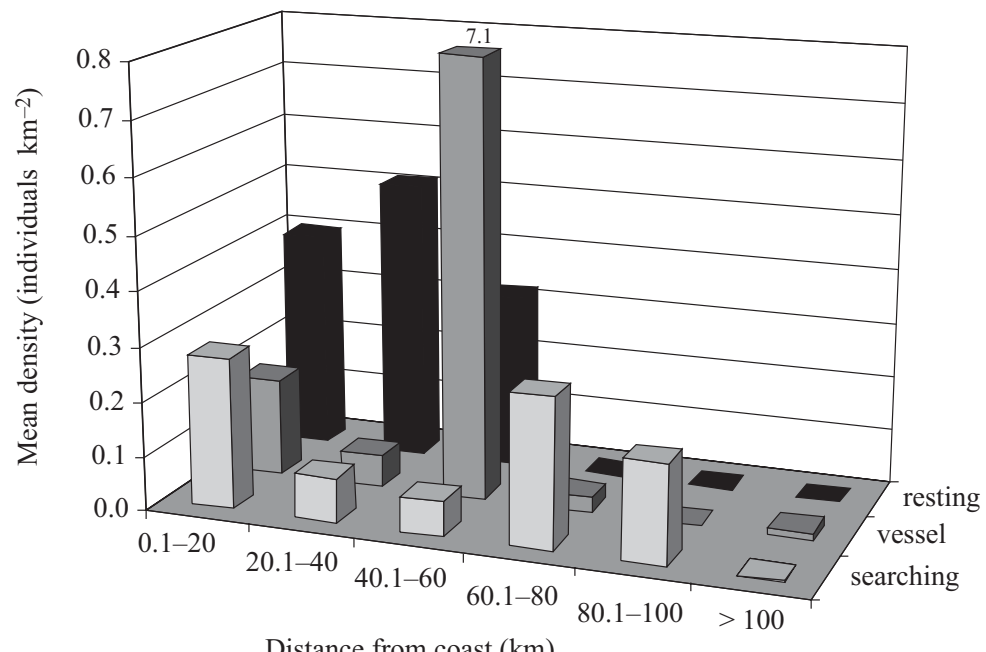

Fig. 8. Larus fuscus. Distance from coast (nearest point, including Wadden Sea islands, but excluding Helgoland) of lesser black-backed gulls resting, associated with fishing vessels (vessel) and searching for or feeding on natural food (searching) 
Table 1. Temporal variation in behaviour and results of $\chi^{2}$-test examining behavioural differences between morning/evening and mid-day hours. ns: not significant

\begin{tabular}{|c|c|c|c|c|}
\hline \multirow{2}{*}{ Time of day (UTC) } & \multicolumn{2}{|c|}{ No. of gulls } & \multirow{2}{*}{$\begin{array}{c}\text { \% displaying } \\
\text { behaviour }\end{array}$} & \multirow{2}{*}{$\chi^{2}$-test } \\
\hline & in transect & displaying behaviour & & \\
\hline \multicolumn{5}{|l|}{ Searching for/feeding on natural prey } \\
\hline $03: 00-08: 59$ and $15: 00-19: 59$ & 551 & 95 & 17.24 & $\chi^{2}=10.25$ \\
\hline $09: 00-14: 59$ & 1144 & 124 & 10.83 & $\mathrm{df}=1$ \\
\hline 03:00-19:59 & 1695 & 219 & 12.92 & $\mathrm{p}<0.001$ \\
\hline \multicolumn{5}{|l|}{ Associated with fishing vessel } \\
\hline $03: 00-08: 59$ and 15:00-19:59 & 551 & 19 & 3.45 & $\chi^{2}=137.87$ \\
\hline $09: 00-14: 59$ & 1144 & 411 & 35.93 & $\mathrm{df}=1$ \\
\hline 03:00-19:59 & 1695 & 430 & 25.37 & $\mathrm{p}<0.001$ \\
\hline \multicolumn{5}{|l|}{ Resting } \\
\hline 03:00-08:59 and 15:00-19:59 & 551 & 88 & 15.97 & \\
\hline 09:00-14:59 & 1144 & 181 & 15.82 & ns \\
\hline 03:00-19:59 & 1695 & 269 & 15.59 & \\
\hline
\end{tabular}

In addition to natural food, the lesser black-backed gulls following fishing vessels were observed in high numbers (Fig. 5). During May and June, the months of main breeding activity, gull densities were not significantly associated with areas of highest fishing effort (data for 1990 to 1995, Spearman rank correlation; $r_{s}=0.165 ;$ not significant) as there were numerous gulls close to the shore (Fig. 10). During July and August, the highest gull densities shifted to the areas of highest fishing effort $\left(\mathrm{r}_{\mathrm{s}}=0.915 ; \mathrm{p}<\right.$ 0.001, Fig. 11).

Analysis of the main food items of lesser blackbacked gulls from Norderney collected during the egg stage in 2002 revealed fishes and terrestrial

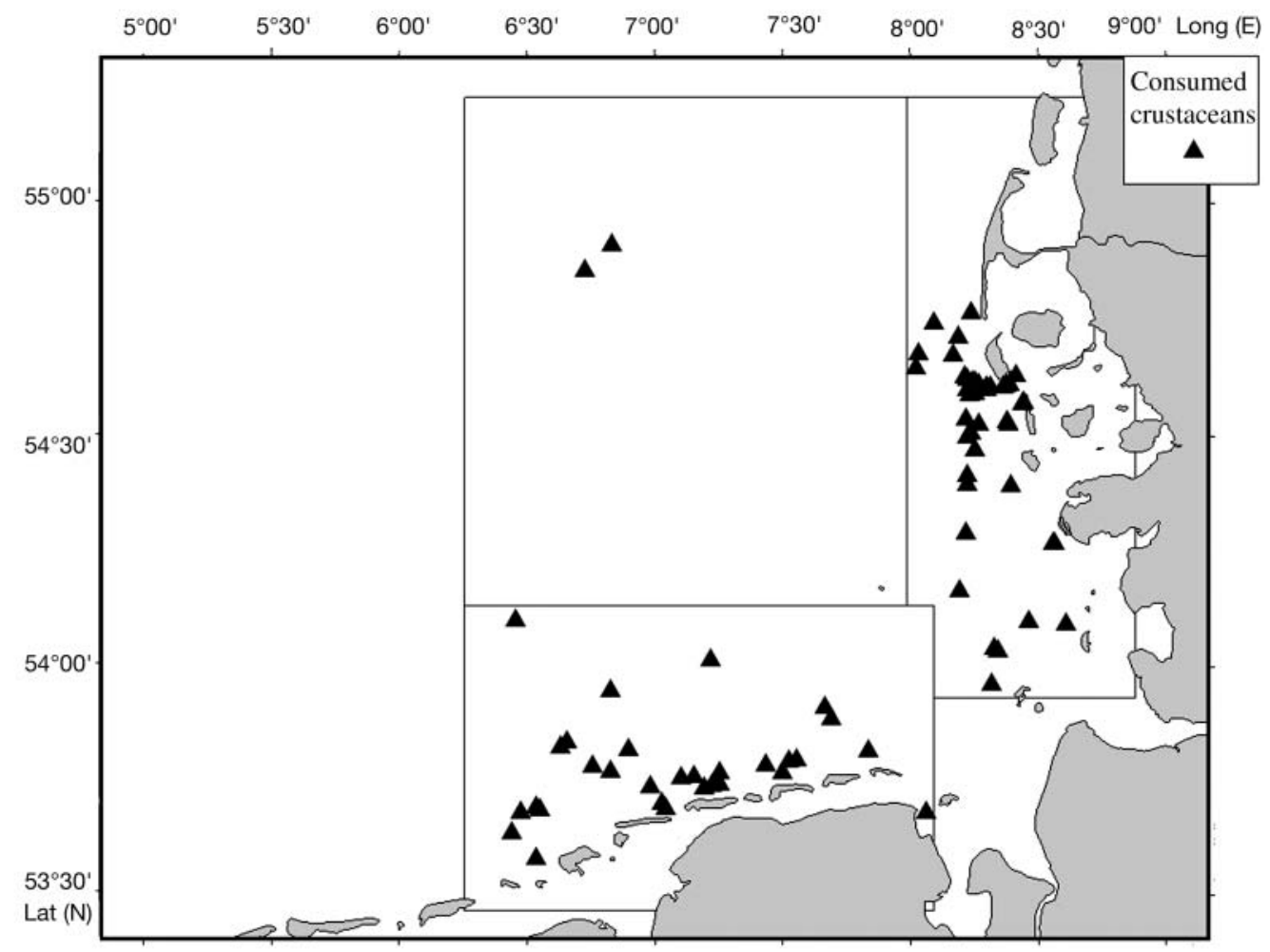

Fig. 9. Larus fuscus. Crustaceans consumed by lesser black-backed gulls in May-August 2002 and boxes used in statistical analyses 


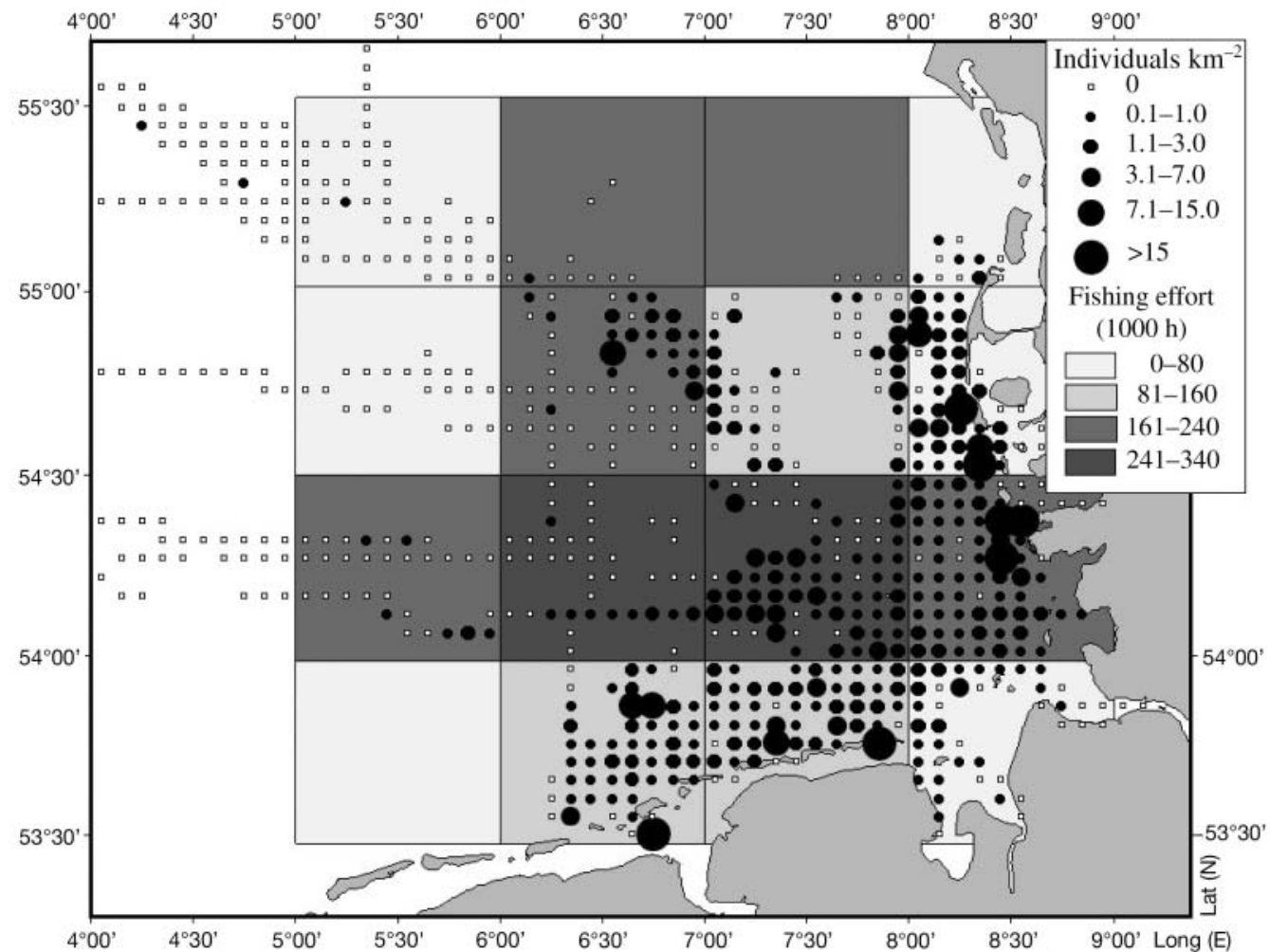

Fig. 10. Larus fuscus. Distribution of lesser black-backed gulls and fishing effort in May-June 1990-1995. Grid represents statistical ICES rectangles. Data for fishing effort from Jennings et al. (1999)

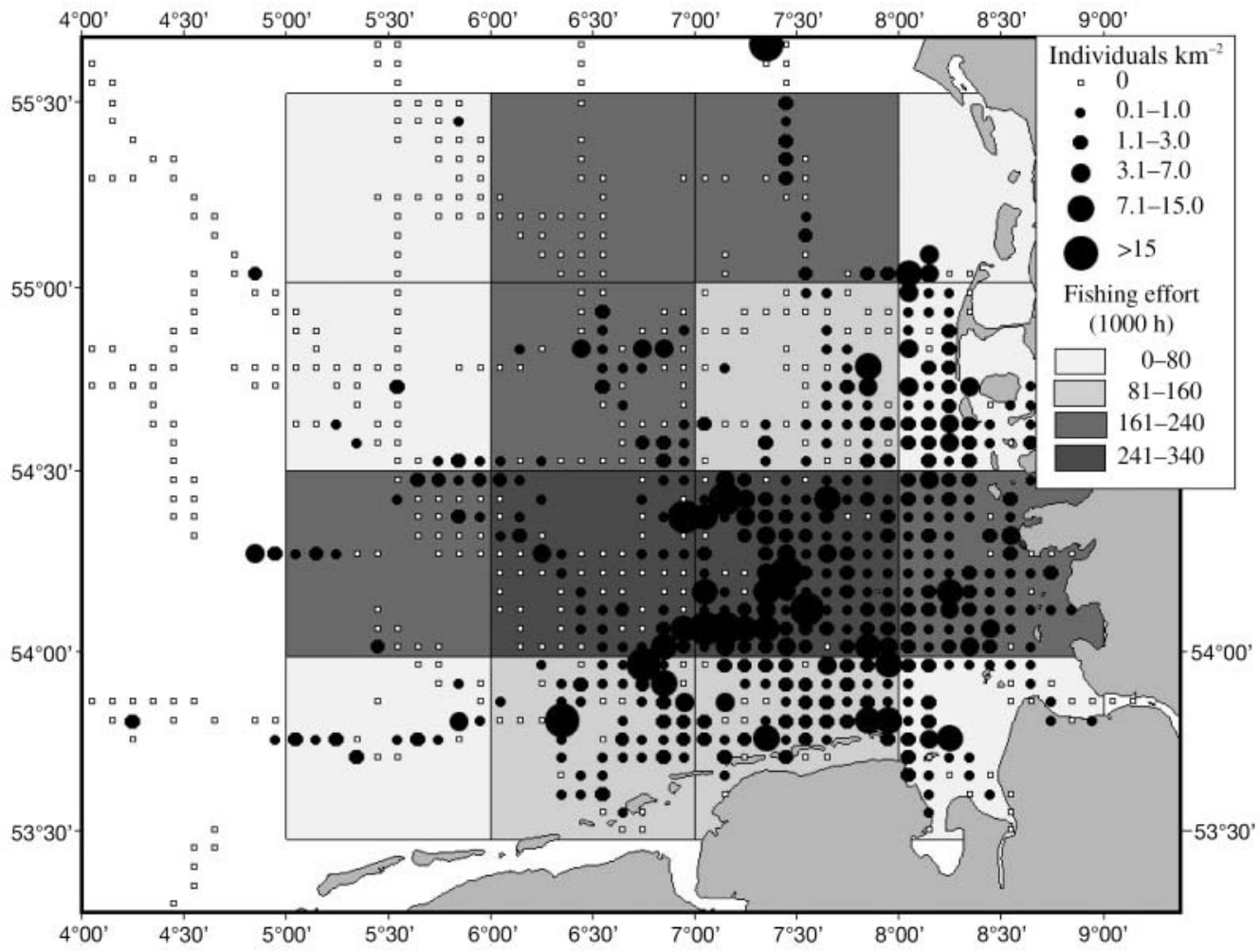

Fig. 11. Larus fuscus. Distribution of lesser black-backed gulls and fishing effort in July-August 1990-1995. Grid represents statistical ICES rectangles. Data for fishing effort from Jennings et al. (1999) 
Table 2. Results of 5-way ANOVA of 2 scenarios: flight activity of gulls leaving colony, and flight activity of gulls returning to colony. n.s: not significant

\begin{tabular}{|lrcc|}
\hline Parameter & df & $F$ & $\mathrm{p}$ \\
\hline Heading out to sea & & & \\
$\quad$ Main und combined effects & 24 & 5.766 & $<0.001$ \\
Time of day & 4 & 5.072 & $<0.001$ \\
Tide & 3 & 4.605 & $<0.01$ \\
Wind force & 2 & 1.127 & $\mathrm{~ns}$ \\
Wind direction & 1 & 11.272 & $<0.001$ \\
Presence of fishing vessels $(<10 \mathrm{~km})$ & 1 & 8.234 & $<0.01$ \\
Time of day $\times$ tide & 12 & 2.293 & $<0.05$ \\
Wind direction $\times$ wind force & 1 & 5.215 & $<0.05$ \\
Returning to colony & & & \\
Main und combined effects & 24 & 3.503 & $<0.001$ \\
Time of day & 4 & 7.925 & $<0.001$ \\
Tide & 3 & 0.782 & $\mathrm{~ns}$ \\
Wind force & 2 & 1.018 & $\mathrm{~ns}$ \\
Wind direction & 1 & 0.775 & $\mathrm{~ns}$ \\
Presence of fishing vessels $(<10 \mathrm{~km})$ & 1 & 0.497 & $\mathrm{~ns}$ \\
Time of day $\times$ tide & 12 & 1.808 & $\mathrm{~ns}$ \\
Wind direction $\times$ wind force & 1 & 3.668 & $\mathrm{~ns}$ \\
& & & \\
\hline
\end{tabular}

invertebrates to be the most frequent food items (both appearing in $45 \%$ of the samples), followed by Liocarcinus spp. (23\%). During the chick-rearing period, Liocarcinus spp. was the most common prey type $(44 \%)$ with fishes ranking second $(28 \%)$ and terrestrial invertebrates less frequent $(18 \%)$. For the samples collected from Amrum in 2003 during the egg stage, Liocarcinus spp. was the most frequent dietary item $(71 \%)$, terrestrial invertebrates $(28 \%)$ and fishes
(15\%) were less common. During the chick stage, the proportion of Liocarcinus spp. was slightly higher $(78 \%)$, while the proportions of terrestrial invertebrates $(17 \%)$ and fishes $(7 \%)$ were lower (see also Table 3).

\section{Flight activity near the colony}

Flight activity of lesser black-backed gulls near the colony of Norderney was due to various factors. The best ANOVA model was for birds leaving the colony $\left(\mathrm{R}^{2}=0.51\right)$, followed by that for birds returning to the colony $\left(\mathrm{R}^{2}=\right.$ 0.39).

For both scenarios, time of day had a significant effect on flight activity, with a distinct pattern of strong morning and evening flight activity (means of $154.7 \pm 37.5$ and $195.2 \pm 32.1$ gulls crossed the counting line between 03:00 and 08:59 h and 15:00 and 19:59 h respectively). In contrast, flight activity decreased substantially during mid-day (mean of 87.5 \pm 18.1 gulls between 09:00 and 14:59 h). Wind force was the only variable which had no significant effect, while tide, wind direction, abundance of fishing vessels and the combined effects were significant only for gulls leaving the colony (Table 2).

Table 3. Comparison of results of different studies on diet of lesser black-backed gull in area of German Bight. Values are frequency of occurrence $(\%)$. Breeding status of chicks: breeding stage (B), egg stage (E)

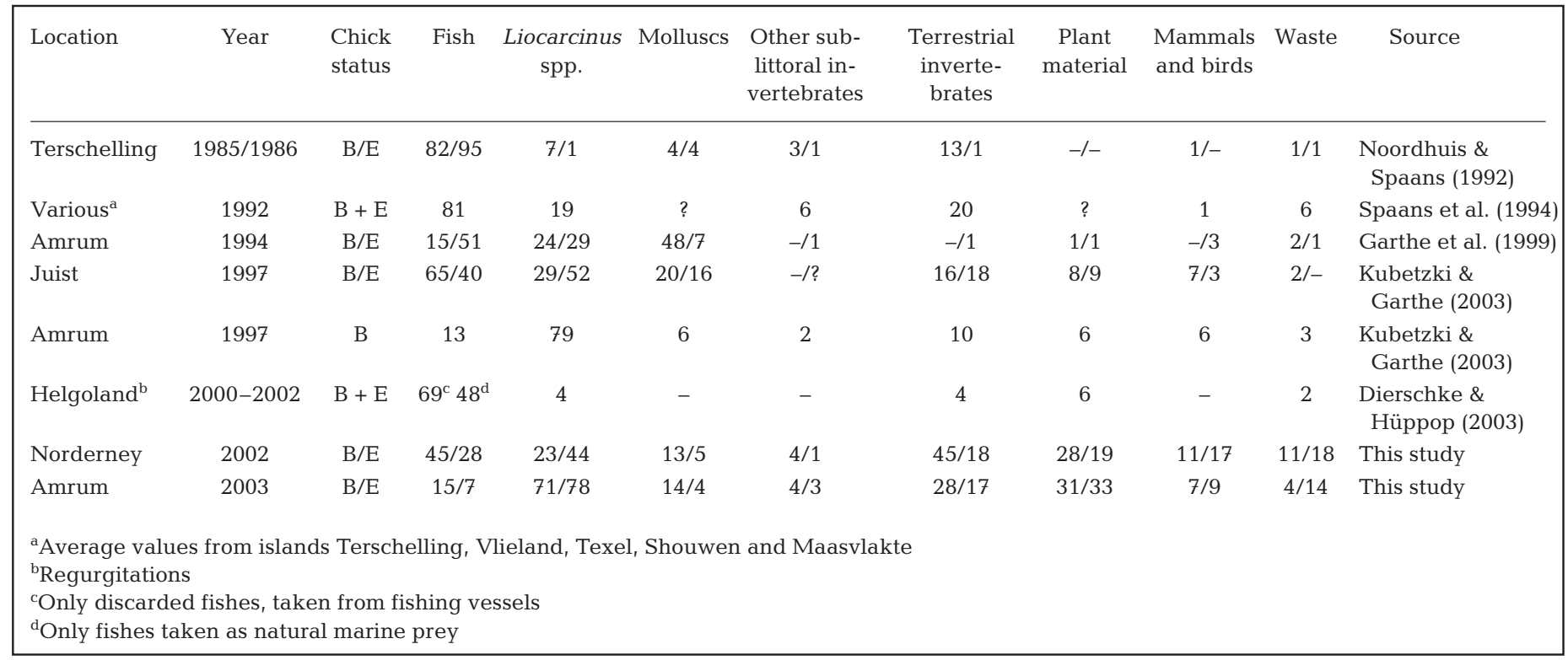




\section{DISCUSSION}

Compared to other gull species, lesser black-backed gulls have a very extensive feeding range, resulting in a widespread distribution (see also Pearson 1968, Camphuysen 1995, Kubetzki \& Garthe 2003). In the Wadden Sea area, the breeding population has increased almost exponentially during recent years (e.g. Spaans 1998, Garthe et al. 2000). The shift in areas of high abundance at sea during the 3 study periods is partly due to increases in the number of breeding pairs, resulting in an exponential population growth off the German North Sea coast since the mid1990s. The average numbers of breeding pairs for the 3 periods (1992 to 1996: 7143 pairs; 1996 to 1997: 17700 pairs; 2000 to 2002: 30997 pairs) (Südbeck \& Hälterlein 1994, 1995, 1999, 2001, Hälterlein \& Südbeck 1996, 1998, Garthe et al. 2000) are reflected in the increasing densities at sea. However, it is still not clear what has caused particular hot-spots of lesser black-backed gull abundance and the reason for their shifts in the German Bight during the study period. To achieve insight into possible reasons, an investigation of the species' behaviour patterns and main food types was made. This study is one of the first to undertake such an approach.

The results of dietary analyses may help to achieve a better understanding of the feeding ecology of this species and its relations to anthropogenic, terrestrial and natural food from the sea. With an ability to dive only $0.5 \mathrm{~m}$ deep (Goethe 1975) or to take food items floating close to the surface by dipping, the lesser black-backed gull is only capable of hunting prey which occurs on or at least temporarily near the water surface. In both colonies studied, fishes and Liocarcinus spp. were the gull's most common food. Fishes can be captured naturally, but can also originate from discards or by-catch of fishing vessels. When identifying fishes from pellets of lesser black-backed gulls to species level, several authors found a high amount of fish species (such as gadids) that live close to the bottom, and thus can only become available to gulls through anthropogenic activities (e.g. Noordhuis \& Spaans 1992, Spaans et al. 1994, Camphuysen 1995, Garthe et al. 1999, Dierschke \& Hüppop 2003). Discard experiments have shown that lesser black-backed gulls following fishing vessels took up mainly fishes, and hardly fed on discarded crustaceans (e.g. Camphuysen et al. 1995, Walter \& Becker 1997, our own obs.). Thus it is very likely that the high proportion of Liocarcinus spp. found in the diet samples in both colonies were obtained by natural feeding. Frequent observations of lesser black-backed gulls feeding on crustaceans during the research cruises in 2002 (Fig. 9) strongly support this conclusion. Considering the high quantities of
Liocarcinus spp. in the pellets, especially on Amrum in 2003, this type of prey obviously makes a very significant contribution to the diet of lesser black-backed gulls. This becomes even more obvious when considering the fishes/Liocarcinus spp. ratio for this particular colony (Table 3). The capture of free-living pelagic crustaceans has also been recorded in other gull species elsewhere (Stewart et al. 1984, Munilla 1997).

Comparison of the results of earlier studies on pellets with those of this study (Table 3) revealed the following: the abundance of Liocarcinus spp. in 1985 and 1986 (Noordhuis \& Spaans 1992) as well as in 1992 (Spaans et al. 1994) was very low, but increased in subsequent years (except for Norderney in 2002 and Helgoland in 2003). This could be due to 2 factors. First, the study sites were different; thus, comparison is not possible without taking into account possible differences in the availability of the crustaceans in the different areas. Second, abundance of Liocarcinus spp. seems to have increased during the last $20 \mathrm{yr}$. The following supports this: (1) An analysis of by-catches revealed an increase in the abundance of Liocarcinus spp. during the late 1980s, at least for the eastern German Bight (Tiews 1983, 1990); unfortunately no similar analysis has since been made. (2) Many studies have demonstrated that fishery activities support benthic scavengers such as Liocarcinus spp. that feed on dead or damaged fishes and other discarded species (e.g. Ramsay et al. 1997, Demestre et al. 2000, Frid \& Clark 2000). (3) Liocarcinus spp. are present in significantly higher abundance in areas that have recently been trawled (Fonds \& Groenewold 2000, Groenewold \& Fonds 2000). Rumohr \& Kujawski (2000) compared benthos data from 1902 to 1912 with data from 1986, and the numbers revealed of that species were 5 times higher in 1986; the authors named the possible effects of fisheries as responsible for that increase. (4) Besides direct effects of fishery, overfishing of large demersal fish species feeding on small crustaceans or its larvae could have led to an increase in crustacean abundance; e.g. the cod Gadus morhua is known to feed on benthic crustaceans to a large extent (e.g. Casas \& Paz 1996, Gerasimova \& Kiseleva 1998). However, considering the strong difference in the diet of the lesser black-backed gull between Juist and Amrum in 1997 and between Helgoland and Amrum in 2003 (Table 3) recorded in the present study, location would seem to play a decisive role in abundance of this species.

An obvious seasonal change in the diet of the lesser black-backed gull was indicated by dietary analysis and by the increasing number of gulls observed hunting crustaceans at sea. On Amrum as well as on Norderney, there was an increase in the proportion of Liocarcinus spp. in the diet from the egg to the chick stage. These results agree with those of other studies 
that found a seasonal increase of crustaceans in the diet of gulls (Munilla 1997, Garthe et al. 1999, Kubetzki \& Garthe 2003, present Table 3). Taking into account the fact that crustaceans have a much lower energy value than fishes (Cummins \& Wuycheck 1971) and that fish diet can significantly enhance the survival rates of gull chicks (Pierotti \& Annett 1990, Spaans et al. 1994), it is not clear why Liocarcinus spp. dominated the diet during the chick-rearing period. Again there may be more than 1 explanation for this. (1) There are many examples showing that the food choice of gulls can change during the season according to food availability (e.g. Burger 1976, Curtis et al. 1985, Sjöberg 1989, Pierotti \& Annett 1990). Analysing the by-catch of the German brown shrimp fisheries, Tiews (1983) found a strong increase in abundance of Liocarcinus spp. from spring to autumn. Aagaard et al. (1995) described increased activity of the shore crab Carcinus maenas in late summer and autumn, and this might also apply to Liocarcinus spp. Thus increased feeding on crustaceans despite their lower energetic profitability may be the result of their superabundance at certain times of the year. (2) The pure energetic value of food is not always the main factor in food selection. Especially during the breeding season, birds require specific nutrients in their diet (Bezzel \& Prinzinger 1990). Calcium plays a major role in gull nutrition; it is an important component of eggshells and is necessary for bone development of chicks (e.g. Pierotti \& Annett 1990, 1991). Liocarcinus spp. (and molluscs) may prove a valuable source of calcium, and capture of Liocarcinus spp. at sea would enable Larus fuscus to avoid the heavy competition of other gulls species on tidal shore flats.

Exploitation of crustaceans could potentially lead to niche-partitioning with other gull species that do not use this source of food so intensively. Recent dietary analyses have revealed no major utilisation of Liocarcinus spp. by mew, black-headed or herring gulls, which mainly forage in the sublittoral zone (Dernedde 1993, Kubetzki \& Garthe 2003). In addition, competition for discards or by-catch of shrimp trawlers can be avoided by preying on crustaceans. Lesser black-backed gulls follow shrimp trawlers in coastal waters in high numbers at comparatively short distances from their colonies (Fig. 6), and are in intense competition with other gull species (e.g. Camphuysen 1995, Walter \& Becker 1997). In contrast, beam trawlers, which mainly fish far offshore, are followed almost exclusively by lesser black-backed gulls (often in high numbers) far away from their colonies, even during the breeding season (Camphuysen 1995, Walter \& Becker 1997, our own obs.). After the breeding season, fishery activity determines the distribution of lesser black-backed gulls at sea even more strongly (Figs. 10 \& 11).
Thus, by feeding mainly on pelagic crustaceans near the coast and following fishing vessels in offshore areas, the lesser black-backed gull tends to adopt 2 different feeding strategies resulting in different spatial and temporal distribution patterns. These findings are supported by observations of 2 different modes of departure on foraging trips in a lesser black-backed gull colony. During the breeding season, the gulls either leave the colony in direct flight, or use a typical search flight, often diving for crustaceans in the early morning and evening hours (Schwemmer 2003). This indicates that the former were heading towards particular feeding sites such as beam trawlers fishing far off the coast, whereas the latter were searching for natural food, hunting for Liocarcinus spp. as their main food item.

Besides Liocarcinus spp. and discards, pelagic fishes have to be taken into account as a further source of natural food. However, the importance of this food item for the lesser black-backed gull is not clear (Camphuysen 1995, Kubetzki \& Garthe 2003). Spaans et al. (1994) found that pelagic shoaling fishes play a major role in the gulls' diet during chick-rearing. Dietary analysis and behavioural observations in the present study revealed utilisation of pelagic fishes by the lesser black-backed gull to be rare, indicating that this food may be taken as a supplementary rather then a major prey type (see also Table 3). However, pelagic fishes are probably underestimated in dietary analyses because of their high digestibility (see e.g. Duffy \& Jackson 1986).

Robust relationships between avian feeding behaviour and daily activity patterns of their prey has been found in many studies (e.g. Bohl 1980, Piersma et al. 1988, Sjöberg 1989). For the lesser black-backed gull, this also appears to be the case. Increased availability of their main food item, Liocarcinus spp., could have caused the strong peaks of flight activity in the morning and evening, although birds tend to show strong diurnal activity patterns with morning and evening peaks independent of external stimuli (Aschoff 1966).

In terms of seasonal activity, the lesser black-backed gull tended to move into areas of higher fishing effort during July and August. Here, time of the year did not seem to be the most important factor. Movements of the gull during this period could be due to the end of breeding activity, allowing foraging at longer distances from the shore, in the areas of higher food availability provided by fishing vessels.

In conclusion, the behaviour of lesser black-backed gulls in the SE North Sea reflects anthropogenic and natural factors by distinct patterns and changes in atsea distribution, diet and prey-related foraging. Because of its high abundance and characteristic offshore distribution, this species might prove a suitable 
bio-indicator species for evaluating changing conditions in both the natural marine environment and anthropogenic activities (see also Montevecchi 1993).

Acknowledgements. This study greatly benefited from shipbased survey data collected with the financial support of the Federal Environmental Ministry, the Federal Agency for Nature Conservation, the 'Ornithologische Arbeitsgemeinschaft für Schleswig-Holstein \& Hamburg e.V.' and the 'Freunde und Förderer der Inselstation der Vogelwarte Helgoland e.V.'. Field observations were carried out by many observers over the years. Many private and governmental institutions permitted us to work on their boats. Ship-based surveys in 2002 were partly funded by the projects 'Erfassung von Rastvögeln in der deutschen AWZ von Nord- und Ostsee (ERASNO)' and 'Rastvogelvorkommen und Offshore-Windkraftnutzung: Analyse des Konfliktpotenzials für die deutsche Nord- und Ostsee' (Sub-project 5 of MINOS). M. Mercker, P. Todt and S. Weiel helped with data collection during the cruises in 2002. We are grateful to S. Ehrich and P. Cornus for providing data on fishing effort. C. J. Camphuysen was instrumental in discussing behaviour of seabirds at sea. W. A. Montevecchi, V. Dierschke and U. Kubetzki improved an earlier version of this paper by helpful comments. The 'Öömrang Ferian i.f.' assisted in the collection of dietary samples and the 'Untere Landschaftsbehörde, Kreis Nordfriesland' provided access to the nature reserve on Amrum. The 'Niedersächsischer Landesbetrieb für Wasserwirtschaft und Küstenschutz' enabled us to stay near the colony during the field work on Norderney.

\section{LITERATURE CITED}

Aagaard A, Warman CG, Depledge MH (1995) Tidal and seasonal changes in the temporal and spatial distribution of foraging Carcinus maenas in the weakly tidal littoral zone of Kerteminde Fjord, Denmark. Mar Ecol Prog Ser 122: 165-172

Ainley DA, Ribic CA, Fraser WR (1992) Does prey preference affect habitat choice in Antarctic seabirds? Mar Ecol Prog Ser 90:207-221

Aschoff J (1966) Circadian activity pattern with two peaks. Ecology 47:657-662

Ashmole NP (1971) Sea bird ecology and the marine environment. In: Farner DS, King JR (eds) Avian biology. Academic Press, New York, p 224-286

Bezzel E, Prinzinger R (1990) Ornithologie. Ulmer, Stuttgart

Bohl E (1980) Diel pattern of pelagic distribution and feeding in planktivorous fish. Oecologia 44:368-375

Buckland ST, Anderson DR, Burnham KP, Laake JL (1993) Distance sampling: estimating abundance of biological populations. Chapman \& Hall, London

Burger J (1976) Daily and seasonal activity patterns in breeding laughing gulls. Auk 93:308-323

Camphuysen CJ (1995) Herring gull Larus argentatus and lesser black-backed gull $L$. fuscus feeding at fishing vessels in the breeding season: competitive scavenging versus effective flying. Ardea 83:365-380

Camphuysen CJ, Garthe S (2004) Recording foraging seabirds at sea: standardised recording and coding of foraging behaviour and multi-species foraging associations. Atlantic Seabirds 6:1-32

Camphuysen CJ, Calvo B, Durinck J, Ensor K and 7 others (1995) Consumption of discards by seabirds in the North Sea. Rep No. 1995-5. Neth Inst Sea Res, Den Burg, Texel
Casas JM, Paz J (1996) Recent changes in the feeding of cod (Gadus morhua) off the Flemish Cap, Newfoundland 1998-1993. ICES J Mar Sci 53:750-756

Cummins KW, Wuycheck JC (1971) Caloric equivalents for investigations in ecological energetics. Mitt Int Ver Theor Angew Limnol 18:1-158

Curtis DJ, Galbraith CG, Smyth JC, Thompson DBA (1985) Seasonal variations in prey selection by estuarine blackheaded gulls (Larus ridibundus). Estuar Coast Shelf Sci 21: 75-89

Demestre M, Sánchez P, Kaiser MJ (2000) The behavioural response of benthic scavengers to otter-trawling disturbance in the Mediterranean. In: Kaiser MJ, de Groot SJ (eds) The effect of fishing on non-target species and habitats. Blackwell Science, Oxford, p 121-129

Dernedde T (1993) Vergleichende Untersuchungen zur Nahrungszusammensetzung von Silbermöwe (Larus argentatus), Sturmmöwe (L. canus) und Lachmöwe (L. ridibundus) im Königshafen/Sylt. Corax 15:222-240

Dierschke AK, Hüppop O (2003) Langfristige Veränderungen in der Ernährung von Silbermöwen (Larus argentatus) auf Helgoland unter dem Einfluß der Fischerei mit Vergleichen zur Heringsmöwe (Larus fuscus). Seevögel 24:3-15

Duffy DC, Jackson S (1986) Diet studies of seabirds: a review of methods. Waterbirds 9:1-17

Fonds M, Groenewold S (2000) Food subsidies generated by the beam-trawl fishery in the southern North Sea. In: Kaiser MJ, de Groot SJ (eds) The effect of fishing on nontarget species and habitats. Blackwell Science, Oxford, p 130-150

Frid CLJ, Clark RA (2000) Long-term changes in North Sea benthos: discerning the role of fisheries. In: Kaiser MJ, de Groot SJ (eds) The effect of fishing on non-target species and habitats. Blackwell Science, Oxford, p 198-216

Garthe S (1997) Influence of hydrography, fishing activity, and colony location on summer seabird distribution in the south-eastern North Sea. ICES J Mar Sci 54:566-577

Garthe S, Hüppop O (2000) Aktuelle Entwicklungen beim Seabirds-at-Sea-Programm in Deutschland. Vogelwelt 121:301-305

Garthe S, Freyer T, Hüppop O, Wölke D (1999) Breeding lesser black-backed gulls Larus graellsii and herring gulls Larus argentatus: coexistence or competition? Ardea 87: $227-236$

Garthe S, Flore BO, Hälterlein B, Hüppop O, Kubetzki U, Südbeck P (2000) Brutbestandsentwicklung der Möwen (Laridae) an der deutschen Nordseeküste in der zweiten Hälfte des 20. Jahrhunderts. Vogelwelt 121:1-13

Garthe S, Hüppop O, Weichler T (2002) Anleitung zur Erfassung von Seevögeln auf See von Schiffen. Seevögel 23: $47-55$

Gerasimova OV, Kiseleva VM (1998) Long-term variations in cod distribution and feeding on the Newfoundland Shelf in spring and summer. Northwest Atl Fish Organ Sci Counc Stud 31:79-110

Goethe F (1975) Zur Biologie der Heringsmöwe Larus fuscus unter besonderer Berücksichtigung ethologischer Aspekte. Ornis Fennica 52:5-12

Groenewold S, Fonds M (2000) Effects on benthic scavengers of discards and damaged benthos produced by the beamtrawl fishery in the southern North Sea. ICES J Mar Sci 57: 1395-1406

Hälterlein B, Südbeck P (1996) Brutvogelbestände an der deutschen Nordseeküste im Jahre 1994-Achte Erfassung durch die Arbeitsgemeinschaft 'Seevogelschutz'. Seevögel 17:5-11

Hälterlein B, Südbeck P (1998) Brutvogelbestände an der 
deutschen Nordseeküste im Jahre 1996-Zehnte Erfassung durch die Arbeitsgemeinschaft 'Seevogelschutz'. Seevögel 19:73-79

Hunt GLJ (1990) The pelagic distribution of marine birds in a heterogeneous environment. Polar Res 8:43-54

Hunt GLJ, Hunt MW (1973) Habitat partitioning by foraging gulls in Maine and northwestern Europe. Auk 90:827-839

Hunt GLJ, Russell RW, Coyle KO, Weingartner T (1998) Comparative foraging ecology of planktivorous auklets in relation to ocean physics and prey availability. Mar Ecol Prog Ser 167:241-259

Jennings S, Alvsvåg J, Cotter AJR, Ehrich S and 5 others (1999) Fishing effects in northeast Atlantic shelf seas: patterns in fishing effort, diversity and community structure. III. International trawling effort in the North Sea: an analysis of spatial and temporal trends. Fish Res 40:125-134

Kubetzki U, Garthe S (2003) Distribution, diet and habitat selection by four sympatrical gull species in the southeastern North Sea. Mar Biol 143:199-207

Montevecchi WA (1993) Birds as indicators of change in marine prey stocks. In: Furness RW, Greenwood JJD (eds) Birds as monitors of environmental change. Chapman \& Hall, London, p 216-266

Munilla I (1997) Henslow's swimming crab (Polybius henslowii) as an important food for yellow-legged gulls (Larus cachinnans) in NW Spain. ICES J Mar Sci 54:631-634

Noordhuis R, Spaans AL (1992) Interspecific competition for food between herring Larus argentatus and lesser blackbacked gulls L. fuscus in the Dutch Wadden Sea area. Ardea 80:115-132

Pearson TH (1968) The feeding biology of sea-bird species breeding on the Farne Islands, Northumberland. J Anim Ecol 37:521-552

Pierotti R, Annett CA (1990) Diet and reproductive output in seabirds: food choices by individual, free-living animals can affect survival of offspring. BioScience 40:568-574

Pierotti R, Annett CA (1991) Diet choice in the herring gull: constraints imposed by reproductive and ecological factors. Ecology 72:319-328

Piersma T, Lindeboom R, van Eerden MR (1988) Foraging rhythm of great crested grebes Podiceps cristatus adjusted to diel variations in the vertical distribution of their preyOsmerus eperlanus in a shallow eutrophic lake in The Netherlands. Oecologia 76:481-486

Ramsay K, Kaiser MJ, Moore PG, Hughes RN (1997) Consumption of fisheries discards by benthic scavengers: utilisation of energy subsidies in different marine habitats. J Anim Ecol 66:884-896

Ribic CA, Ainley DG (1997) The relationships of seabird assemblages to physical habitat features in Pacific equatorial waters during spring 1984-1991. ICES J Mar Sci 54: 593-599

Rumohr H, Kujawski T (2000) The impact of trawl fishery on the epifauna of the southern North Sea. ICES J Mar Sci 57: 1389-1394

Schwemmer P (2003) Verbreitung und Aktivitätsmuster der

Editorial responsibility: Otto Kinne (Editor-in-Chief), Oldendorf/Luhe, Germany
Heringsmöwe (Larus fuscus) in der Deutschen Bucht. MS thesis, University of Kiel

Sjöberg K (1989) Time-related predator/prey interactions between birds and fish in a northern Swedish river. Oecologia 80:1-10

Spaans AL (1998) Breeding lesser black-backed gulls (Larus graellsii) in The Netherlands during the 20th century. Sula 12:175-184

Spaans AL, Bukacińska M, Bukaciński D, van Swelm ND (1994) The relationship between food supply, reproductive parameters and population dynamics in Dutch lesser black-backed gulls (Larus fuscus): a pilot study. BEON Report 94-15. Institute for Forestry and Nature Research, Wageningen

Stewart BS, Yochem PK, Schreiber R (1984) Pelagic red crabs as food for gulls: a possible benefit of El Niño. Condor 86: $341-342$

Strann KB, Vader W (1992) The nominate lesser black-backed gull Larus fuscus fuscus, a gull with a tern-like feeding biology, and its recent decrease in northern Norway. Ardea 133-142

Südbeck P, Hälterlein B (1994) Brutvogelbestände an der deutschen Nordseeküste im Jahre 1992-Sechste Erfassung durch die Arbeitsgemeinschaft 'Seevogelschutz'. Seevögel 14:11-15

Südbeck P, Hälterlein B (1995) Brutvogelbestände an der deutschen Nordseeküste im Jahre 1993-Siebte Erfassung durch die Arbeitsgemeinschaft 'Seevogelschutz'. Seevögel 16:25-30

Südbeck P, Hälterlein B (1999) Brutvogelbestände an der deutschen Nordseeküste im Jahre 1997 - 11. Erfassung durch die Arbeitsgemeinschaft 'Seevogelschutz'. Seevögel 20:9-16

Südbeck P, Hälterlein B (2001) Brutvogelbestände an der deutschen Nordseeküste 1998 und 1999-12. und 13. Erfassung durch die Arbeitsgemeinschaft 'Seevogelschutz'. Seevögel 22:41-48

Tasker ML, Jones HP, Dixon T, Blake BF (1984) Counting seabirds at sea from ships: a review of methods employed and a suggestion for a standardized approach. Auk 101: $567-577$

Tiews K (1983) Über die Veränderung im Auftreten von Fischen und Krebsen im Beifang der deutschen Garnelenfischerei während der Jahre 1954-1981: ein Beitrag zur Ökologie des deutschen Wattenmeeeres und zum biologischen Monitoring von Ökosystemen im Meer. Archiv FischWiss 34:1-156

Tiews K (1990) 35-Jahres-Trend (1954-1988) der Häufigkeit von 25 Fisch- und Krebstierbeständen an der deutschen Nordseeküste. Arch FischWiss 40:39-48

Walter U, Becker PH (1994) The significance of discards from the brown shrimp fisheries for seabirds in the Wadden Sea — preliminary results. Ophelia 6:253-262

Walter U, Becker PH (1997) Occurrence and consumption of seabirds scavenging on shrimp trawler discards in the Wadden Sea. ICES J Mar Sci 54:684-694

Submitted: February 17, 2004; Accepted: July 6, 2004

Proofs received from author(s): January 6, 2004 